\title{
The Craft, the Trade and the Elephants
}

Esmond Bradley Martin

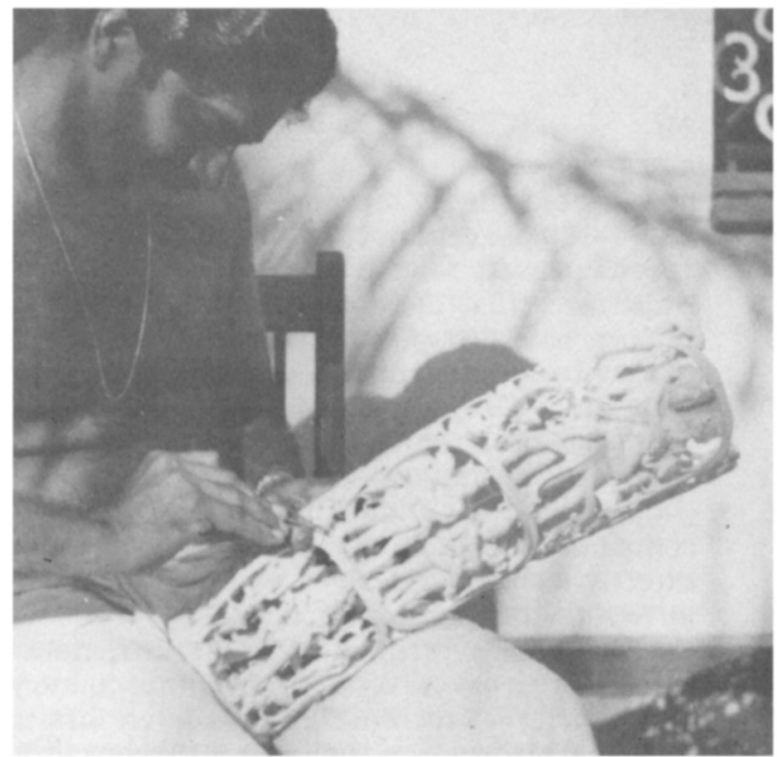

Carved ivory objects are widely sold in India, and up to 90 per cent to foreigners, either in exports or tourists' accompanied luggage, which is a loophole in the government's otherwise complete ban on exports made from Indian ivory. Partly because of this ban, which has probably reduced elephant poaching in India, the ivory trade depends on imported African ivory, and the rise in price in recent years has been so steep that most carvers cannot affort to buy it. As a result the larger traders are turning to other crafts, and carvers are being re-trained to work in wood. This sad decline of an ancient skilled craft may, however, ease some of the pressure on both Indian and African elephants.

For hundreds of years ivory has played an important role in India's culture. When Indians began carving ivory is not certain, but archaeologists have found worked ivory of the first century BC in Rajasthan. In the latter half of the 18th century, when the maharajahs and other princes had consolidated their political and economic control, ivory carving, painting and inlay in furniture became world renowned. Today, however, fundamental changes are affecting the Indian ivory trade.

There has always been a shortage of domestic ivory in India, and for centuries ivory has been imported from Africa, but not in large quantities until the early decades of the 19th century. Zanzibar businessmen were the major suppliers from the 1830s to 1964, when the Zanzibar Revolution disrupted the market. In 1848 for instance Zanzibar traders sent 143 tons to India; from 1875 to 1881 India imported 250 tons a year, mostly from Zanzibar. During and just after World War II, India imported about the same amount, averaging 246 tons yearly, as for the $1875-81$ period, but from 1948 to $1976 / 7$ the quantity declined enormously: from $1960 / 1$ to $1976 / 7$ the average imports were only 37 tons. From 1965/6 to 1973/4 Kenya, Tanzania and Uganda supplied 99 per cent of India's imported ivory, but since 1974/5 middlemen in Europe, Dubai and Hong Kong have been supplying about 47 per cent of the total.

One reason for the recent sharp decline in India's ivory imports is that Hong Kong and other merchants have been willing to pay higher prices than 
merchants in India. Secondly, unlike Hong Kong, India has a high import duty -120 per cent in 1978 . And thirdly the Indian government now requires special permits for the export of worked ivory, which involve bureaucratic procedures that discourage both imports and exports. Since 1973/4 ivory imports have dropped to a yearly average of just six tons.

Raw ivory imports are handled mainly by ten companies in Bombay and New Delhi, all specialising in this business. At least two have been in operation for over 50 years; one in Bombay, dating back to 1901, was typical in having subsidiary operations - small factories where ivory is worked and also retail shops scattered around the country. Until recently, buyers from the ivory companies came to Zanzibar, Dar es Salaam and Mombasa to purchase ivory directly from local dealers, who were mainly of Indian origin, or to buy at government-sponsored auctions.

Despite the current government restrictions and taxes, India still today has many more ivory carvers than any other country in the world. I estimate that in December 1978 there were 7200 carvers (craftsmen who spend at least 50 per cent of their working time on ivory), but this is probably half what it was a decade ago when much more ivory was available.

The two largest concentrations of craftsmen are in Kerala (3000) and the Delhi area (2000). Others are in Jaipur (800), Mysore City (600), Benares (200), Murshidabad (200), Amritsar (150), and Gujerat State (120); the remaining 130 work in small groups throughout the country.

All ivory carvers are men, the vast majority Hindu, most of them working out of their own homes. Almost none receive a salary, but are paid according to output; they earn between $200(\$ 25)$ and 2000 rupees a month. Because ivory is now so expensive that few carvers can afford to buy it, the merchants supply the pieces and pay the carvers for what they produce. A Hindu god carving, seven inches high, will take one man 10 to 14 days; for this he will be paid approximately 300 rupees. Some employers, particularly the large companies, provide a place for their craftsmen to work, and also tools and food, but this is the exception rather than the rule.

\section{Machinery in the North}

Today in northern India, craftsmen generally use the electric lathe machines that were gradually introduced after World War II to produce their carvings, and only put on the finishing touches by hand. Furthermore, the items made in Delhi, the Punjab, Rajasthan and Bengal consist of the more mundane types of bangles, lamps, chess sets, paintings, miniature Taj Mahal replicas and letter openers. In the South, however, ivory carvers shun machines and use only hand tools - chisels, rasps, drills, files, etc., and their workmanship is of higher quality and more individual. Obviously this takes longer, and so, despite the fact that there are more craftsmen in the South, considerably less ivory is worked there. The South's main centre is Trivandrum, capital of Kerala. Religious sculptures are the most commonly produced items, and these include not only Hindu gods but also Christian saints and Crucifixion scenes. The Trivandrum craftsmen are moreover well known for carving intricate figures on whole tusks.

To protect the remaining 14,000 wild elephants in India, the government in the mid-1970s passed legislation prohibiting the export of any object made out of new or antique Indian ivory. Thus, for the export trade and, in practice, for 
most of the carving industry, only African ivory is legally used. The carvers actually prefer African ivory because it has less tendency to crack. It is probably true to say that the restriction on Indian ivory exports has cut elephant poaching in India. But the one serious loophole in the new legislation is the lack of control over ivory exported as accompanied baggage.

Because the price of ivory has soared, some Indian ivory trophies (especially in the form of antique tusks formerly used to decorate doorways) has come onto the market. After a piece has been carved, painted or used in inlay work it is extremely difficult to ascertain whether or not it is of Indian origin, so unscrupulous Indian traders can easily trick the authorities by using cheaper, older ivory for tourist items. While the ivory shipped out of India has to have an export permit (only granted by officials in New Delhi when they are satisfied that the ivory was legally imported from sources abroad), bona fide tourists are not required to obtain export permits for the ivory pieces they buy and take out of the country.

Ivory objects are sold in every part of India. The largest concentrations are in the main tourist centres: Bombay, Madras, Jaipur, Delhi, Bangalore and Calcutta, where almost every deluxe and first-class hotel has a shop selling ivory trinkets. Prices vary enormously for the same items, but on average one would pay $\$ 15$ for a plain ivory bracelet, $\$ 35$ for a carved one, $\$ 175$ for a $12 \mathrm{in}$. Hindu statue, and $\$ 1250$ for a medium-sized rosewood table inlaid with ivory. The most expensive new item I saw in December 1978 was a 40in. long, 27in. high sculpture of a chariot pulled by six bullocks for $\$ 18,750$. These prices reflect the cost of raw ivory in India, which, due to the 120 per cent import duty, was $\$ 187$ (1500 rupees) per kilo in December 1978 when the world market price was only $\$ 75$ a kilo.

Today foreigners buy between 85 and 90 per cent of all carved ivory in India. Between 1970 and 1977, according to the official Customs records, ivory exports went mainly to the USA, France, Japan, Italy, Yugoslavia, Czechoslavakia, USSR, West Germany, UK and Spain; the value over this seven-year period averaged $\$ 607,359$ a year. However, this represents only the ivory legally exported by retailers and wholesalers through official channels; it excludes all smuggled ivory and ivory taken out by tourists or Indians themselves. Furthermore, the value of the legally exported ivory has risen tremendously from $\$ 246,354$ in $1970 / 1$ to $\$ 1,638,724$ in $1976 / 7$, primarily due to the upsurge in raw ivory prices. A kilo in 1971 was just $\$ 10$.

Today the ivory traders are pessimistic about their future. They do not have enough raw ivory to supply the 7200 carvers even if, as the World Wildlife Fund suspects, another two tons are smuggled in every year. Antique Indian ivory is rapidly vanishing, and wild elephants have decreased severely over the last thirty years. It is impossible to estimate how much Indian ivory the carvers use. Found ivory made available by the Forest Department in 1978 was just three tons. Over the last few years, the average amount from all sources, including imports, has probably been less than three kilos a year for each carver. The traders feel they cannot afford the present prices for legally imported ivory; in 1978 they paid an 80 per cent increase on the previous year's price, and they also fear that before 1982 the Indian government will ban all ivory imports in a bid to strengthen their own elephant conservation measures. Consequently, the large ivory companies are diversifying into other tourist-orientated crafts. The ivory carvers can be re-trained to work in other 
mediums. Their apprenticeship in ivory requires some eight years, but, after serving that they can learn wood carving in a matter of three months, and many are now working in sandalwood and earning about the same money.

Before World War II a considerable amount of ivory was bought by Indians, especially by Hindu brides who required ivory bangles, but today there is little demand. Only in Gujerat and Rajasthan do girls still wear these for marriage ceremonies. Indian women now prefer gold, silver or plastic jewellery. In India raw ivory has never been stored as an investment or as a hedge against inflation, as it has in Hong Kong and Japan, nor do Indian ivory traders stockpile more than six months' supply. Indian Muslims do not care for ivory at all because they consider it dead animal matter.

In conclusion, the Indian ivory trade has fallen to a low ebb, due mainly to extremely sharp price increases, purchasing difficulties and the fear of further government restrictions. Carvers are turning their skills to other mediums. What they do produce in ivory panders to foreign buyers, often without taste, who accept poor copies of masterpieces and even encourage the painting of crude and vulgar scenes on ivory, instead of supporting creative artistry. What a travesty of one of India's finest traditions!

\section{References}

BALFOUR, EDWARD 1885. The Cyclopaedia of India and of Eastern and Southern Asia, Commercial, Industrial and Scientific. Bernard Quaritch, London.

GOVERNMENT OF INDIA. Department of Commercial Intelligence and Statistics, Calcutta. Accounts Relating to the Sea-borne Trade and Navigation of India, 1946-51. Accounts Relating to the Foreign Sea and Airborne Trade and Navigation of India, 1952-3. Accounts Relating to the Foreign (Sea, Air and Land) Trade and Navigation of India, 1954-6. Monthly Statistics of the Foreign Trade of India, 1957-77.

MARTIN, ESMOND BRADLEY. Pers. obs. Field work in India, December 1978-January 1979.

Dr Esmond Bradley Martin, Villa Langata, PO Box 15510, Mbagathi, Nairobi, Kenya.

\section{Bawean Island Reserve}

More than 4500 hectares on Bawean Island, equal to nearly a quarter of the whole island, has been declared a reserve for Indonesia's rare and endemic Bawean deer Axis kuhli. This marks the end of a two-year WWF research project carried out by Drs Sumaryoto Atmoseodirdjo and Raleigh A. Blouch, who have produced the management plan. All deer hunting has been stopped, eight rangers are patrolling the reserve, and some teak areas are being thinned to allow growth of the bushy cover that the deer like. When the two research workers started their project the deer were so shy only three animals were seen in 300 hours' field work; now they are frequently seen.

\section{Crocodiles v. Fishermen}

In their 1976 crocodile survey of Sri Lanka, Rom and Zai Whitaker assessed total numbers of Crocodylus palustris at 2800 , with 275 breeding females, and of $C$. porosus at 375 , with 40 breeding females. In their report, published in the Bombay Natural History Society Fournal (April 1979) they discuss the problem of public relations in crocodile conservation: "Crocodiles do not have the good looks and appeal of the elephant or tiger . . . but the concept that the ecological roles of all wildlife are relevant to our environment is gaining favour . . . Many large-scale fisheries have come to grief when the crocodiles were wiped out ...'Fishermen accuse crocodiles of being competitors for fish, but in fact crocodiles may feed more on the sedentary predatory fish, such as catfish. Crocodiles that attack livestock or humans, they say, should be caught and transferred, a job for which a squad of expert handlers must be trained. 